日本原子力研究開発機構機関リポジトリ

Japan Atomic Energy Agency Institutional Repository

\begin{tabular}{|c|l|}
\hline Title & $\begin{array}{l}\text { Corrosion behavior of ODS steels with several chromium contents } \\
\text { in hot nitric acid solutions }\end{array}$ \\
\hline Author(s) & Tanno Takashi, Takeuchi Masayuki, Otsuka Satoshi, Kaito Takeji \\
\hline Citation & Journal of Nuclear Materials, 494, p.219-226 (2017) \\
\hline Text Version & Author Accepted Manuscript \\
\hline URL & $\underline{\text { https://jopss.jaea.go.jp/search/servlet/search?5057672 }}$ \\
\hline DOI & $\underline{\text { https://doi.org/10.1016/j.jnucmat.2017.07.008 }}$ \\
\hline Right & $\begin{array}{l}\text { C } 2017 . \text { This manuscript version is made available under the } \\
\text { CC-BY-NC-ND 4.0 license } \\
\text { http://creativecommons.org/licenses/by-nc-nd/4.0/ }\end{array}$ \\
\hline
\end{tabular}




\section{Corrosion behavior of ODS steels with several chromium contents in hot nitric acid solutions}

Takashi Tanno ${ }^{\mathrm{a},}{ }^{*}$, Masayuki Takeuchi ${ }^{\mathrm{b}}$, Satoshi Ohtsukaa ${ }^{\mathrm{a}}$, Takeji Kaito ${ }^{\mathrm{a}}$

aJapan Atomic Energy Agency, Oarai-machi Higashiibaraki-gun, Ibaraki 311-1393, Japan

bJapan Atomic Energy Agency, Tokai-mura Naka-gun, Ibaraki 319-1195, Japan

*Corresponding author

E-mail address: tanno.takashi@jaea.go.jp

4002 Narita-cho Oarai-machi Higashi-Ibaraki-gun, 311-1393 Ibaraki, Japan

Abstract

Oxide dispersion strengthened (ODS) steel cladding tubes have been developed for fast reactors. Tempered martensitic ODS steels with 9 and $11 \mathrm{wt} \%$ of chromium (9Cr-, 11Cr-ODS steel) are the candidate material in research being carried out at JAEA. In this work, fundamental immersion tests and electrochemical tests of 9 to 12Cr-ODS steels were systematically conducted in various nitric acid solutions at $95^{\circ} \mathrm{C}$. The corrosion rate decreased exponentially with effective solute chromium concentration $\left(\mathrm{Cr}_{\text {eff }}\right)$ and nitric acid concentration. Addition of vanadium (V) and ruthenium (Ru) also decreased the corrosion rate. The combination of low $\mathrm{Cr}_{\text {eff }}$ and dilute nitric acid could not avoid the active mass dissolution during active domain at the beginning of immersion, and the corrosion rate was high. Higher $\mathrm{Cr}_{\text {eff }}$ decreased the partial anodic current during the active domain and assisted the passivation of the surface of the steel. Concentrated nitric acid and addition of Ru and V increased partial cathodic current and shifted the corrosion potential to noble side. These effects should have prevented the active mass dissolution and decreased the corrosion rate. 


\section{Introduction}

Fast reactor fuel pins are heavily irradiated at high temperature, and they are loaded a high internal pressure due to emission of fission product (FP) gases from the fuel pellets. In order to maintain the durability and efficiency of the fuel pins, cladding tube materials should have excellent high temperature strength and irradiation resistance. Oxide dispersion strengthened (ODS) steels have been developed as candidate materials for the cladding tubes because of their good high temperature strength and irradiation resistance owing to their fine microstructure that acts as an irradiation defect sink [1-6]. Tempered martensitic ODS steels with 9 and 11 wt\% chromium (9Cr-, 11CrODS steel) were developed in Japan Atomic Energy Agency (JAEA) and have been the primary candidate materials for research done in JAEA [7-9]. These materials have the above advantages for use as fast reactor fuel pin materials and an third advantage of structure controllability by $\alpha-\gamma$ phase transformation [10].

After use, spent fuel pins are chopped and immersed into a hot nitric acid solution to leach out the fuel in the reprocessing process. In order to estimate the influence of corrosion products from cladding tubes on the reprocessing process, the corrosion behavior should be evaluated. In general, high $\mathrm{Cr}(>12 \mathrm{wt} \%)$ steels have good corrosion resistance because a passive layer of $\mathrm{Cr}$ is formed, making them as well-known and widely used as stainless steels. Therefore, the corrosion resistance may be a disadvantage of 9 and 11Cr-ODS steels due to their low $\mathrm{Cr}$ concentration, though the other properties are superior. In fact, high Cr ODS steels have been developed from the view point of corrosion resistance, such as 14Cr-ODS steels, 18Cr-ODS steels, and Al added high Cr ODS steels [1113]. Gwinner et al. [14] reported that a ferritic 18Cr-ODS steel have much better corrosion resistance in nitric acid solutions than that of 9Cr-ODS steel.

The corrosion rate of several JAEA 9Cr-ODS steels in nitric acid solutions has been evaluated and the results suggested that the corrosion rate in nitric acid solutions drastically changes around $9 \mathrm{wt} \% \mathrm{Cr}$ in the nominal content $[15,16]$. The corrosion rate of JAEA 11Cr-ODS steel was lower than that of the 9Cr-ODS steels, though only one lot of the 11Cr-ODS steels has been evaluated as a trial. In addition, these two reports state that the corrosion rate in dilute nitric acid solution was higher than that in concentrated nitric acid solution and in solutions with oxidizing species. This work mainly evaluated the corrosion behavior of 9 to 12Cr-ODS steels in various hot nitric acid solutions. Immersion tests and electrochemical tests were systematically conducted in order to clarify the corrosion behavior associated with the $\mathrm{Cr}$ concentration in the material, the nitric acid concentration and the existence of oxidizing species in the solution. 


\section{Experimental Procedure}

\subsection{Material}

The chemical compositions of martensitic 9 to 12Cr-ODS steels and a ferritic 12Cr-ODS steel tested in this work are as shown in Table 1 . The ODS steels were fabricated by a powder metallurgy process. Raw metal powders and $\mathrm{Y}_{2} \mathrm{O}_{3}$ powder were mechanically alloyed (MAed) in an attritor type ball-mill with a high purity argon (99.9999 wt\%) gas atmosphere. The MAed powders was canned and evacuated to less than $1.3 \times 10^{-3} \mathrm{~Pa}$ at $400{ }^{\circ} \mathrm{C}$. The sealed cans containing the MAed powder were preheated for over $3 \mathrm{~h}$ at $1150{ }^{\circ} \mathrm{C}$, then consolidated into round bars by hot-extrusion at the same temperature. Some of the hot-extruded round bars were rolled into a tube or flat plate shape for other mechanical tests, and the rolled materials were also used for the corrosion tests in this work. The martensitic ODS steels were cured by two step heat treatment to obtain tempered martensitic structure; normalizing for $1 \mathrm{~h}$ at $1050{ }^{\circ} \mathrm{C}$ followed by gas cooling and tempering for $1 \mathrm{~h}$ at $800{ }^{\circ} \mathrm{C}$ followed by gas cooling. For a ferritic ODS steel, recrystallization heat treatment for $30 \mathrm{~min}$ at $1150{ }^{\circ} \mathrm{C}$ followed by furnace cooling was applied. Conventional 11Cr ferritic/martensitic steel (PNC-FMS) and modified 316 steel (PNC316) were also tested as the reference materials. Their chemical compositions are shown in Table 2. The actual solute Cr concentration affecting the passivity is lower than the nominal $\mathrm{Cr}$ content because of the carbide precipitation such as $\mathrm{M}_{23} \mathrm{C}_{6}$ during the tempering heat treatment. In order to clarify the relationship between the corrosion behavior and $\mathrm{Cr}$ concentration, the nominal $\mathrm{Cr}$ content was redefined as the effective solute $\mathrm{Cr}$ concentration $\mathrm{Cr}_{\text {eff. }} \quad$ The $\mathrm{Cr}_{\text {eff }}$ can be roughly calculated with following formula considering the mole-fraction of competitive compounds $(\mathrm{Fe}, \mathrm{Cr})_{23} \mathrm{C}_{6}$, $\mathrm{TiC}, \mathrm{TiO}_{2}$ and $\mathrm{TiN}$, where the excess oxygen $E x . O$ is defined as the value obtained by subtracting oxygen content as $\mathrm{Y}_{2} \mathrm{O}_{3}$ from the total $\mathrm{O}$ content in the steel, $a$ is the $\mathrm{Cr} /(\mathrm{Fe}+\mathrm{Cr})$ ratio in $(\mathrm{Fe}, \mathrm{Cr})_{23} \mathrm{C}_{6}$.

$$
\left[C r_{\text {eff }}\right]=[C r]-23 / 6 \times\{[C]-[T i]+[E x . O] / 2+[N]\} \times a
$$

Previous work also estimated the $\mathrm{Cr}_{\text {eff }}$ using this formula [13], though a thermodynamic calculation using FactSage v.6.4 with FSstel database [17] was done to obtain more realistic $\mathrm{Cr}_{\text {eff }}$ values (Tables 1 and 2) in this work.

\subsection{Immersion test}

The immersion test in various nitric acid solutions was carried out in order to determine the corrosion rates. Five nitric acid solutions and three with oxidizing species were prepared for the test as shown in Table 3. The elements and concentrations of oxidizing species were chosen on the basis of a model case of the spent fuel leaching $[15,16]$. 
The model case has 8 stages of immersion. S1, S2 and S3 solutions correspond to the stage 1 to 3 which the spent fuel is dissolved extensively, intermediately and slightly, respectively. The solutions of stage 4 to 8 are almost 12 mol/L nitric acid solution (12M). According to previous researches [18, 19], the galvanic effect of ruthenium (Ru) is more extensive than that of other FP elements including platinoids. Vanadium (V) is used to simulate the presence of plutonium $(\mathrm{Pu})$ because the standard redox potential $E^{\circ}$ of $\mathrm{V}(+\mathrm{V}) / \mathrm{V}(+\mathrm{IV})$ is close to that of $\mathrm{Pu}(+\mathrm{IV}) / \mathrm{Pu}(+\mathrm{III})$ and $\mathrm{Pu}(+\mathrm{VI}) / \mathrm{Pu}(+\mathrm{IV})[20,21]$

$$
\begin{aligned}
& \mathrm{VO}_{2}^{+}+2 \mathrm{H}^{+}+\mathrm{e}^{-} \leftrightarrow \mathrm{VO}^{2+}+\mathrm{H}_{2} \mathrm{O} \\
& E^{\circ}=991 \mathrm{mV} / \mathrm{SHE} \\
& \mathrm{Pu}^{4+}+\mathrm{e}^{-} \leftrightarrow \mathrm{Pu}^{3+} \\
& E^{\circ}=1006 \mathrm{mV} / \mathrm{SHE} \\
& \mathrm{PuO}_{2}^{2+}+4 \mathrm{H}^{+}+2 \mathrm{e}^{-} \leftrightarrow \mathrm{Pu}^{4+}+2 \mathrm{H}_{2} \mathrm{O} \\
& E^{\circ}=1042 \mathrm{mV} / \mathrm{SHE}
\end{aligned}
$$

Specimens were cut from the materials and mechanically polished to remove the oxidized surface layer before the immersion test. Total surface area of specimens was approximately $20 \mathrm{~cm}^{2}$ for each test condition. The ratio of solution volume to surface area was over $20 \mathrm{~cm}^{3} / \mathrm{cm}^{2}$. The immersion test was carried out for $30 \mathrm{~min}$ at $95{ }^{\circ} \mathrm{C}$. The mass loss of the specimen due to the immersion test was measured, and converted to the corrosion rate using the following density values: $7.83 \mathrm{~g} / \mathrm{cm}^{3}$ for ODS steels and PNC-FMS (BCC structure) and $7.97 \mathrm{~g} / \mathrm{cm}^{3}$ for PNC316 (FCC structure).

After the immersion test, macro photography of the specimen was done to check the surface condition, such as color. Some of specimens were observed by scanning electron microscope (SEM) to check and compare the surface micro morphology. The SEM observation was conducted at two acceleration voltage to confirm the existence of a film. The observed particles were analyzed by energy dispersive X-ray spectrometry (EDS).

\subsection{Electrochemical test}

The electrochemical test consisting of the linear voltammetry test was carried out in order to obtain the polarization curves for discussion of the corrosion behaviors under various combinations of $\mathrm{Cr}_{\text {eff }}$ and nitric acid solutions. The materials and nitric acid solutions were the same as those in the immersion test. Specimens were cut from the materials and mechanically polished, prior to being installed in the Teflon jig with a window. The window was located where the specimen was exposed to the nitric acid solution and was a $1 \mathrm{~cm}^{2}$ circle shape for 
the flat plate specimen and a $0.4 \mathrm{~cm}^{2}$ rectangle shape for the tube specimen.

Initially, the specimen was immersed in the nitric acid solution at $95{ }^{\circ} \mathrm{C}$ and measurement of the immersion potential vs. silver-silver chloride electrode (SSE) was started. The immersion potential became relatively stable in 10 min. After this 10-min immersion, the specimen was slowly polarized to the anodic potential, and the anodic polarization curve was obtained. The cathodic polarization curve was obtained similarly with a new specimen and solution. The potential was swept to 1,200 $\mathrm{mV} / \mathrm{SSE}$ for the anodic polarization curve to confirm the transition from passive domain to trans-passive domain. The sweep range was limited $400 \mathrm{mV}$ from the stable corrosion potential for the cathodic polarization curve, because there were some difficulties for measuring the current for lower potential side, such as a solution leak into the jig by mass dissolution, and current instability due to crevice corrosion. The potential sweep rate was $20 \mathrm{mV} / \mathrm{min}$, which was chosen to grasp the corrosion behavior accurately and to avoid undesirable crevice corrosion due to degradation of the sealing material by long term immersion in the severe corrosive environmental.

\section{Results and discussion}

\subsection{Immersion test}

\subsubsection{Corrosion rate dependence on effective $\mathrm{Cr}$ concentration $\mathrm{Cr}_{\text {eff }}$}

The corrosion rate in the nitric acid solutions depended on the $\mathrm{Cr}_{\text {eff }}$ of the material. And the tendency could be divided into two groups. One was in nitric acid solutions without $\mathrm{Ru}$ and $\mathrm{V}$, and the other was in solutions with $\mathrm{Ru}$ and V. Fig. 1 shows the corrosion rates in the former case. The corrosion rate decreased exponentially with $\mathrm{Cr}_{\text {eff. }}$ The corrosion rate became $1 / 2$ for $1 \mathrm{wt} \% \mathrm{Cr}_{\text {eff }}$ increase ( 1 decade decrease for $3 \mathrm{wt} \% \mathrm{Cr}_{\text {eff }}$ increase) in 3.5M nitric acid solution, and became 1/3 to $1 / 4$ for $1 \mathrm{wt} \% \mathrm{Cr}_{\text {eff }}$ increase ( 1.5 to 2 decade decrease for $3 \mathrm{wt} \% \mathrm{Cr}_{\text {eff }}$ increase) in 5M to 12M nitric acid solutions, respectively. The corrosion rate band shifted to lower with nitric acid concentration increase. In addition, the decrease of corrosion rate stopped between 0.1 and $1.0 \mathrm{~mm} / \mathrm{y}$ in every solution.

In the case of the solutions with $\mathrm{Ru}$ and $\mathrm{V}$, the corrosion rate was divided into two regions as shown in Fig. 2. The corrosion rate was relatively high for low $\mathrm{Cr}_{\text {eff, }}$ however, dropped to a level between 0.1 to $1 \mathrm{~mm} / \mathrm{y}$ at a $\mathrm{Cr}_{\text {eff. }}$. The drop position in S3 solution was at lower $\mathrm{Cr}_{\text {eff }}$ than that in S2 and S1 solutions.

\subsubsection{Corrosion rate dependence on nitric acid solution condition}

The corrosion rate decreased exponentially with nitric acid concentration increase as shown in Fig. $3 . \quad$ The 
corrosion rate band shifted lower with $\mathrm{Cr}_{\text {eff }}$ increase, then, the slope became steep. The decrease of corrosion rate stopped between 0.1 and $1.0 \mathrm{~mm} / \mathrm{y}$. The corrosion rates of PNC-FMS and PNC316 were adequately low, even in 3.5M nitric acid solution, and did not show dependence on nitric acid concentration. PNC-FMS contained a small amount of molybdenum (Mo) which can enhance the passivation. That would be the reason why PNC-FMS showed better corrosion resistance than 20P did, though the $\mathrm{Cr}_{\text {eff }}$ values of both were almost the same. PNC316 also contained the passivation enhancement elements Mo and silicon (Si), but the effect was not clear because of the much higher $\mathrm{Cr}_{\text {eff. }}$ The addition of $\mathrm{Ru}$ and $\mathrm{V}$ into the nitric acid solutions was effective for suppressing higher corrosion rate ( $>10 \mathrm{~mm} / \mathrm{y})$, but the effect was not clear for lower corrosion rate $(<10 \mathrm{~mm} / \mathrm{y})$ as shown in Fig. 4 . The possible mechanism of that is described in section 3.2.1.

\subsubsection{Surface observation}

At the end of the 30-min immersion, the corrosion behavior became a stable state with all test conditions. However, the surface states after the 30-min immersion test could be categorized into two groups as shown by the example macro image in Fig. 5. One was a group for which the color changed from silver to brown or black (designated "B" in Table 4), and the other group retained its silver color (designated "S" in Table 4). When the Creff was higher, the surface remained silver colored even in dilute nitric acid solutions as shown in Table 4 . On the surfaces of "S" group specimens, the scratches were clear as polished, and any corrosion evidence such as a corroded film and residual particle was not confirmed by SEM observation as shown in Fig. 5 (20P / 8M). According to references, the corrosion rate depends on the dissolution of the iron ion until the Cr-rich passive thin layer completely covers the surface [22]. More concentrated nitric acid solution can form passive thinner film, and the concentration of $\mathrm{Cr}$ in the film is higher $[23,24]$. For instance, $\mathrm{XPS} \mathrm{Cr}_{2} \mathrm{O}_{3}$ peak became clear, and $\mathrm{Cr}(\mathrm{OH})_{3}$ peak disappeared owing to increase of nitric acid concentration from 3 to $9 \mathrm{~mol} / \mathrm{L}$ at room temperature [25]. Thus, the surface of the "S” group specimens would be passivated with little dissolution, owing to their high $\mathrm{Cr}_{\text {eff }}$ and/or strong oxidizing power of the solutions. The $\mathrm{Cr}_{\text {eff }}$ on the surface should have been sufficiently high to be passivated immediately under the condition that the corrosion rate was less than $1.0 \mathrm{~mm} / \mathrm{y}$.

On the other hand, the color change from silver to brown or black indicated that the surface could not be passivated immediately. On the surface of "B" group specimen, the scratches by polishing were not clear, and a thick film and many residual particles were confirmed by SEM observation as shown in Fig. 5 (20P / 3.5M). That is the evidence of significant dissolution of the surface corresponding to the higher corrosion rate of "B" group than that of "S" group. 
The particles would be $(\mathrm{Fe}, \mathrm{Cr})_{23} \mathrm{C}_{6}$ because they contained $\mathrm{Cr}, \mathrm{W}$ and $\mathrm{C}$ higher than that in the matrix. In addition, corroded pore with the particles were observed. It is considered that local $\mathrm{Cr}$ concentration was especially low around the particles, and the corrosion was enhanced. The thick film with brown or black color in macro image should be an oxide layer which was formed when Fe preferentially dissolved from the surface at the beginning of the immersion, prior to the formation of a high $\mathrm{Cr}$ passive thin layer. The thick oxide layer may be not enough to protect the metal surface, but the thickness can obstruct the ion migration and/or diffusion between the metal surface and the solution. As a result, the instantaneous corrosion rate would decrease with immersion time because of the oxide layer growth. Finally, Cr would be concentrated enough on the metal surface due to the Fe preferential dissolution with the thick oxide layer formation, then the metal surface would be passivated. Thus, the corrosion rate for 30 min under "B" group conditions should have depended on the corrosion behaviors; Fe preferential dissolution, the oxide layer growth and obstruction of the ion migration by thick oxide layer, and passivation of the metal surface. Qualitatively speaking, higher $\mathrm{Cr}_{\text {eff }}$ material is passivated more easily. More concentrated nitric acid solutions and addition of Ru and V can oxidize the metal surface of the specimen more strongly. These effects should cause the corrosion behavior transition and corrosion rate change.

The color of PNC-FMS after the immersion test in 3.5M was silver, though its $\mathrm{Cr}_{\text {eff }}$ was lower than that of 21P whose color was black after the same test. This fact agrees with the lower corrosion rate of PNC-FMS shown in Fig. 3 and it is suggested that Mo in PNC-FMS could assist the passivation.

\subsection{Electrochemical test}

\subsubsection{Corrosion mechanism of low $\mathrm{Cr}_{\text {eff }}$ ODS steel in nitric acid solutions with and without $\mathrm{Ru}$ and $\mathrm{V}$}

The current stable region is not observed on the polarization curves of MP23 as shown in Fig. 6. But the slope of the anodic polarization curves up to 900 or $1000 \mathrm{mV} / \mathrm{SSE}$ is relatively gentle, hence the region is considered as the passive domain. Therefore, the corrosion potential of MP23 in all solution existed in the passive domain. The measured current direction reversed twice on the cathodic polarization curves in 3.5M and 5M around $400 \mathrm{mV}$. Same current reverse was confirmed also another 9Cr-ODS steel immersed in 3M at room temperature [23]. The current reverse indicated that the partial anodic current exceeded the partial cathodic current. In other concentrated nitric acid solutions and the solutions with Ru and V, the current reverse was not observed.

The electrochemical reaction of nitric acid solution which imposes the redox potential of the solution is the reduction of nitric acid $\mathrm{HNO}_{3}$ into nitrous acid $\mathrm{HNO}_{2}[19,21]$ 


$$
\begin{aligned}
& \mathrm{NO}_{3}{ }^{-}+3 \mathrm{H}^{+}+2 \mathrm{e}^{-} \leftrightarrow \mathrm{HNO}_{2}+\mathrm{H}_{2} \mathrm{O} \\
& E^{\circ}=934 \mathrm{mV} / \mathrm{SHE}
\end{aligned}
$$

Therefore, the redox potential increases with concentration of $\mathrm{NO}_{3}{ }^{-}$and proton $\mathrm{H}^{+}$, and decreases with nitrous acid. The tendency agrees with the shift of the cathodic polarization curve and stable corrosion potential to noble side with nitric acid concentration in this work. In addition, the redox potential increases with also temperature [26]. Fauvet, et al. [19] summarized the corrosion mechanism of stainless steel in nitric acid solution and the solution containing oxidizing species as follows. Nitric acid is indirectly reduced by an autocatalytic mechanism including a charge transfer step and a chemical reaction which regenerates the electro-active species

$$
\begin{aligned}
& \mathrm{HNO}_{2}+\mathrm{H}^{+}+\mathrm{e}^{-} \leftrightarrow \mathrm{NO}+\mathrm{H}_{2} \mathrm{O} \\
& \mathrm{HNO}_{3}+\mathrm{NO} \leftrightarrow \mathrm{HNO}_{2}+\mathrm{NO}_{2} \\
& \mathrm{HNO}_{3}+\mathrm{HNO}_{2} \leftrightarrow 2 \mathrm{NO}_{2}+\mathrm{H}_{2} \mathrm{O}
\end{aligned}
$$

For dilute nitric acid concentration $(<6 \mathrm{~mol} / \mathrm{L})$, the reaction of regeneration of nitrous acid (7) is slow. On the other hand, the reaction (7) is fast for concentrated nitric acid solution ( $>8 \mathrm{~mol} / \mathrm{L})$, because it is enhanced by the high nitric acid concentration, that is, the autocatalytic mechanism. Then, the reaction (8) is supposed to be at equilibrium. In case of the solution containing oxidizing species whose redox potential are higher than that of nitric acid, the reaction of the reduction of the solution is the reduction of the oxidizing species by metallic elements of steel rather than reaction (5). With reference to the mechanism described above, the polarization curve obtained in this work can be interpreted as below.

The partial cathodic current by the reaction (6) and (7) is low for dilute nitric acid solution (3.5M and 5M). Then, the partial cathodic current by the reduction of proton is relatively significant, especially for lower potential.

$$
2 \mathrm{H}^{+}+2 \mathrm{e}^{-} \leftrightarrow \mathrm{H}_{2}
$$

On the other hand, the partial anodic current is provided by oxidation reaction and dissolution reaction of the metal elements of the steel, where “M” in equations means metal.

$$
\begin{aligned}
& \mathrm{M}+\mathrm{nH}_{2} \mathrm{O} \leftrightarrow \mathrm{MO}_{\mathrm{n}}+2 \mathrm{nH}^{+}+2 \mathrm{ne}^{-} \\
& \mathrm{M} \leftrightarrow \mathrm{M}^{\mathrm{n}+}+\mathrm{ne}^{-}
\end{aligned}
$$

Therefore, the following chemical reactions are possible in dilute nitric acid solutions.

(6) $\times 2 n+(10)$

$\mathrm{M}+2 \mathrm{nHNO}_{2} \rightarrow \mathrm{MO}_{\mathrm{n}}+2 \mathrm{nNO}+\mathrm{nH}_{2} \mathrm{O}$

$(9) \times n+(11)$ 
$2 \mathrm{M}+2 \mathrm{nH}^{+} \rightarrow 2 \mathrm{M}^{\mathrm{n}+}+\mathrm{nH}_{2}$

It is considered that the current reverse as shown in Fig.6 was caused by the lowness of the partial cathodic current by the reaction (6). Therefore, the reaction (13) would be not negligible for the potential less than the second reverse potential ( $\sim 500 \mathrm{mV} / \mathrm{SSE})$. That means MP23 in 3.5M and 5M underwent active mass dissolution by the reaction (13), when the specimen polarized to the stable corrosion potential at the beginning of the immersion.

For moderate or more concentrated nitric acid solutions (8M, 10M and $12 \mathrm{M})$, the current revers was not observed, therefore, the partial cathodic current is higher than the partial anodic current even during the active domain. That indicates that the reaction (6) to (8) were enhanced by the autocatalytic mechanism of nitric acid, and the reaction (12) become dominant rather than the reaction (13). As a result, the surface of the specimen would be passivated in rapidly, though MP23 would undergo a certain dissolution as categorized "B" in Table 4 because of lower $\mathrm{Cr}$ concentration of MP23 than that of what so-called stainless steel.

The redox potential of the oxidizing species of $\mathrm{Ru}$ and $\mathrm{V}$ added to the solution in this work is higher than that of nitric acid (5) [21]

$$
\begin{aligned}
& \mathrm{VO}_{2}^{+}+2 \mathrm{H}^{+}+\mathrm{e}^{-} \leftrightarrow \mathrm{VO}^{2+}+\mathrm{H}_{2} \mathrm{O} \\
& E^{\circ}=991 \mathrm{mV} / \mathrm{SHE} \\
& \mathrm{RuO}_{2}+4 \mathrm{H}^{+}+2 \mathrm{e}^{-} \leftrightarrow \mathrm{Ru}^{2+}+2 \mathrm{H}_{2} \mathrm{O} \\
& E^{\circ}=1120 \mathrm{mV} / \mathrm{SHE} \\
& \mathrm{RuO}_{4}+\mathrm{e}^{-} \leftrightarrow \mathrm{RuO}_{4}^{-} \\
& E^{\circ}=1000 \mathrm{mV} / \mathrm{SHE}
\end{aligned}
$$

Ru generally forms ruthenium (+III) nitrocyl $\mathrm{Ru}(\mathrm{NO})^{3+}$ in nitric acid solution, but it can be oxidize to ruthenium (+VIII) tetra-oxide in hot nitric acid solution, and the possibility of the enhancing catalytic effect on the reduction reaction of nitric acid (5) by ruthenium (+IV) dioxide has been also suggested [27]. Therefore, the cathodic reaction should be dominated by the effect of these oxidizing species. This mechanism can explain the stable corrosion potential shift to noble side by the addition of $\mathrm{Ru}$ and $\mathrm{V}$ into the solution. In addition, it is clear that the partial cathodic current was much increased by Ru and V as shown in Fig. 6. These stronger oxidizing power by Ru and V must have assisted to passivate the surface of the specimen immediately, and suppressed the dissolution less than that by the solution without the Ru and V. This effect should be remarkable when the active mass dissolution is avoided. If the concentrated nitric acid solution and/or high $\mathrm{Cr}_{\text {eff }}$ could prevent the active mass dissolution, the amount of dissolution would be small regardless of whether the solution contained Ru and V or not. That is 
considered to be the reason why the effect of addition of $\mathrm{Ru}$ and $\mathrm{V}$ was not clear for lower corrosion rate $(<10 \mathrm{~mm} / \mathrm{y})$ as shown in Fig. 4.

\subsection{2 $\mathrm{Cr}_{\text {eff }}$ effect on corrosion behavior and mechanism}

The steel with higher $\mathrm{Cr}_{\text {eff }}$ than that of 15P, except for 20P, did not undergo the current reverse in 3.5M for which oxidizing power is the weakest among all the solutions as shown in Fig. 7. Although the polarization curve suggests that 20P would undergo an active dissolution, the current reverse section for 20P was narrow, and the anodic current in this section was much lower than that for MP23. Therefore, the amount of dissolution of 20P before passivation could be not large. Actually, the corrosion rate of 20P in 3.5M was lower than that of 15P. These results indicated that the enrichment of $\mathrm{Cr}_{\text {eff }}$ can decrease the partial anodic current during the active domain, and prevent the active mass dissolution. In addition, the anodic current during the passive domain tended to decrease with $\mathrm{Cr}_{\text {eff. }}$ The corrosion rate of the steel with higher $\mathrm{Cr}_{\text {eff }}$ at the stable passive state for a long term will be lower. According to a previous work [28], the surface of a 15Cr-ODS steel is covered by a passive film consisted of $\mathrm{Cr}_{2} \mathrm{O}_{3}$ after immersion into a dilute nitric acid solution (1M, room temperature). On the other hand, another 11Cr-ODS steel in the report is covered by a film consisted of $\mathrm{Cr}(\mathrm{OH})_{3}$ and $\mathrm{Cr}_{2} \mathrm{O}_{3}$ after the same solution. That indicates that higher $\mathrm{Cr}_{\text {eff }}$ forms more protective passive film, and supports the effect of high $\mathrm{Cr}_{\text {eff }}$ in this work.

The effects of $\mathrm{Cr}_{\text {eff, }}$ nitric acid concentration and addition of $\mathrm{Ru}$ and $\mathrm{V}$, which make oxidizing species, are summarized in Fig. 8 on the basis of the results obtained in this work and the above discussion.

\section{Summary}

In order to understand the corrosion behavior of 9 to 12Cr-ODS steels in a fuel reprocessing process, short term (30 min) immersion test and electrochemical test in hot nitric acid solutions were carried out. Especially, this work focused on the effects of $\mathrm{Cr}_{\text {eff, }}$ nitric acid concentration and addition of $\mathrm{Ru}$ and $\mathrm{V}$ which make oxidative species. The knowledges obtained in this work are as follows.

(1) The corrosion rate of the ODS steels for 30 min decreases exponentially with $\mathrm{Cr}_{\text {eff. }}$ The corrosion rate become $1 / 2$ or $1 / 4$ for $1 \mathrm{wt} \% \mathrm{Cr}_{\text {eff }}$ increase. The corrosion rate in nitric solutions with $\mathrm{Ru}$ and $\mathrm{V}$ drops over 1 decade at a $\mathrm{Cr}_{\text {eff. }}$ The drop point depends on the concentration of nitric acid, $\mathrm{Ru}$ and $\mathrm{V}$ in the solution.

(2) The corrosion rate of the ODS steels for 30 min decreases exponentially with also nitric acid concentration 
increase. The decrease slope becomes steep with $\mathrm{Cr}_{\text {eff }}$ increase. The addition of $\mathrm{Ru}$ and $\mathrm{V}$ decreases the corrosion rate, the effect is especially remarkable for the combination of low $\mathrm{Cr}_{\text {eff }}$ and dilute nitric acid solution corresponding to high corrosion rate.

(3) The corrosion rate decrease stops between 0.1 and $1.0 \mathrm{~mm} / \mathrm{y}$ when the combination of the steel and solution

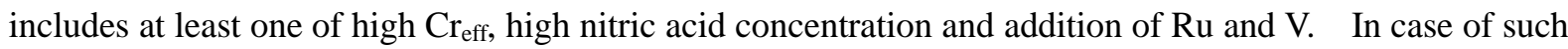
condition, the surface is hardly corroded for short term.

(4) The partial cathodic current by the reduction of dilute nitric acid solution is low. The partial anodic current of low $\mathrm{Cr}_{\text {eff }}$ material during active domain is high. Thereby, the combination of low $\mathrm{Cr}_{\text {eff }}$ steel and low nitric acid concentration cannot avoid an active mass dissolution at the beginning of the immersion, and increases the corrosion rate for short term immersion.

(5) High $\mathrm{Cr}_{\text {eff }}$ steel, concentrated nitric acid solution and addition of $\mathrm{Ru}$ and $\mathrm{V}$ can prevent the active mass dissolution owing to low partial anodic current during the active domain and/or high partial cathodic current by the strong oxidizing power of the solution. The combination of them can assist to passivate the surface immediately, and decrease the corrosion rate for short term immersion. 


\section{References}

[1] R.L. Klueh, J.P. Shingledeker, R.W. Swindeman, D.T. Holzer, Oxide dispersion-strengthened steels: A comparison of some commercial and experimental alloys, J. Nucl. Mater. 341 (2005) 103-114.

[2] P. Yvon, F. Carre, Structural materials challenges for advanced reactor systems, J. Nucl. Mater. 385 (2009) 217222.

[3] A. De Bremaecker, Past research and fabrication conducted at SCK-CEN on ferritic ODS alloys used as cladding for FBR’s fuel pins, J. Nucl. Mater. 428 (2012) 13-30.

[4] P. Dubuisson, Y. de Carlan, V. Garat, M. Blat, ODS Ferritic/martensitic alloys for Sodium Fast Reactor fuel pin cladding, J. Nucl. Mater. 428 (2012) 6-12.

[5] A.A. Nikitina, V.S. Ageev, A.P. Chukanov, V.V. Tsvelev, N.P. Porezanov, O.A. Kruglov, R\&D of ferriticmartensitic steel EP450 ODS for fuel pin claddings of prospective fast reactors, J. Nucl. Mater. 428 (2012) 117124.

[6] S. Ukai, T. Okuda, M. Fujiwara, T. Kobayashi, S. Mizuta, H. Nakashima, Characterization of High Temperature Creep Properties in Recrystallized 12Cr-ODS Ferritic Steel Claddings, J. Nucl. Sci. Tech. 39 (2002) 872-879.

[7] S. Ohtsuka, S. Ukai, H. Sakasegawa, M. Fujiwara, T. Kaito, T. Narita, Nano-mesoscopic structural characterization of 9Cr-ODS martensitic steel for improving creep strength, J. Nucl. Mater. 367-370 (2007) 160165.

[8] S. Ohtsuka, S. Ukai, M. Fujiwara, Nano-mesoscopic structural control in 9CrODS ferritic/martensitic steels, J. Nucl. Mater. 351 (2006) 241-246.

[9] T. Tanno, S. Ohtsuka, Y. Yano, T. Kaito, K. Tanaka, Effects of manufacturing process on impact properties and microstructures of ODS steels, J. Nucl. Mater. 455 (2014) 480-485.

[10] S. Ukai, S. Mizuta, M. Fujiwara, T. Okuda, T. Kobayashi, Development of 9Cr-ODS Martensitic Steel Claddings for Fuel Pins by means of Ferrite to Austenite Phase Transformation, J. Nucl. Sci. Tech. 39 (2002) 778-788.

[11] S. Ukai, S. Ohtsuka, T. Kaito, Y. de Carlan, J. Ribis, J. Malaplate, Structural materials for Generation IV nuclear reactors, Woodhead publishing, Cambridge (2017) pp. 357-414.

[12] C.C. Eiselt, H. Schendzielorz, A. Seubert, B. Hary, Y. de Carlan, P. Diano, B. Perrin, D. Cedat, ODS-materials for high temperature applications in advanced nuclear systems, Nucl. Mater. Energy 9 (2016) 22-28.

[13] A. Kimura, R. Kasada, N. Iwata, H. Kishimoto, C.H. Zhang, J. Isselin, P. Dou, et al., Development of Al added high-Cr ODS steels for fuel cladding of next generation nuclear systems, J. Nucl. Mater. 417 (2011) 176-179. 
[14] B. Gwinner, M. Auroy, D. Mas, A. Saint-Jevin, S. Pasquier-Tilliette, Impact of the use of the ferritic/martensitic ODS steels cladding on the fuel reprocessing PUREX process, J. Nucl. Mater. 428 (2012) 110-116.

[15] M. Takeuchi, M. Inoue, S. Koyama, T. Koizumi, Corrosion property of 9Cr-ODS steel in nitric acid solution for spent nuclear fuel reprocessing, Proc. of Global 2013, Salt Lake City, USA, Sep. 29 - Oct. 3, 2013, Paper No.8107.

[16] M. Inoue, H. Ikeuchi, M. Takeuchi, S. Koyama, M. Suto, Dissolutions of Oxide Dispersion Strengthened Ferritic Steels in Various Nitric Acid Solutions -Martensitic 9Cr-ODS Steels-, JAEA-Research 2011-057 (2012). [in Japanese]

[17] C. W. Bale, E. Bélisle, P. Chartrand, S. A. Decterov, G. Eriksson, K. Hack, I. H. Jung, Y. B. Kang, J. Melançon, A. D. Pelton, C. Robelin, S. Petersen, FactSage thermochemical software and databases — recent developments , Calphad 33 (2009) 295-311.

[18] S. Takeda, T. Koizumi, T. Nagai, M. Takeuchi, T. Kato, K. Kawanobe, K. Fujisaku, T. Nemoto, Corrosion performance of metal materials in reprocessing solution of spent nuclear fuel, JNC TN8400 2002-007 (2001). [in Japanese]

[19] P. Fauvet, F. Balbaud, R. Robin, Q.-T. Tran, A. Mudnier, D. Espinoux, Corrosion mechanisms of austenitic stainless steels in nitric media used in reprocessing plants, J. Nucl. Mater 375 (2008) 52-64.

[20] M. Pourbaix, Atlas of Electrochemical Equilibria in Aqueous Solutions, Pergamon Press, Oxford (1974).

[21] CRC handbook of chemistry and physics $91^{\text {st }}$ Ed., W.M. Haynes, D.R. Lide (Eds.), CRC press, Boca Raton (2010).

[22] T. Shibata, Passivation and passive film, in Stainless Steel Handbook $3^{\text {rd }}$ Ed., Nikkan Kogyo Shimbun Ltd., Tokyo (1995) pp. 251-256. [in Japanese]

[23] S. Ningshen, M Sakairi, K. Suzuki, S. Ukai, The surface characterization and corrosion resistance of $11 \% \mathrm{Cr}$ ferritic/martensitic and 9-15\% Cr ODS steels for nuclear fuel reprocessing application, J. Solid State Electrochem 18 (2014) 411-425.

[24] S. Ningshen, M Sakairi, K. Suzuki, S. Ukai, Corrosion resistance of 9\% Cr oxide dispersion strengthend steel in different electrolytic media, Corrosion 69 No.9 (2013) 863-874.

[25] S. Ningshen, M Sakairi, K. Suzuki, S. Ukai, The corrosion resistance and passive film compositions of 12\% Cr and 15\% Cr oxide dispersion strengthened steels in nitric acid media, Corros. Sci. 78 (2014) 322-334.

[26] M. Takeuchi, G.O.H. Whillock, Calculation of $\mathrm{HNO}_{2}$ concentration from redox potential in $\mathrm{HNO}_{3}-\mathrm{H}_{2} \mathrm{O}$ system 
as an aid to understanding the cathodic reaction of nitric acid corrosion, Zairyo-to-kankyo 51 (2002) 549-554.

[27] Y. Arai, T. Honda, S. Kobayashi, Corrosion behaviors nad electrochemical properties of stainless steel in boiling nitric acid solution containing metal species, Boshoku Gijutsu 39 (1990) 169-174. [in Japanese]

[28] M. Sakairi, S. Ningshen, K. Suzuki, S. Ukai, Corrosion study and passive film characterization of 11\% Cr F/M and 15\% Cr ODS steels, J. Civil. Eng. Archit. 7 No.8 (2013) 940-955. 


\section{Figure captions}

Fig. 1 Dependence of corrosion rate in nitric acid solutions for $30 \mathrm{~min}$ at $95^{\circ} \mathrm{C}$ on $\mathrm{Cr}_{\text {eff. }}$.

Fig. 2 Dependence of corrosion rate in nitric acid solutions with Ru and V for 30 min at $95^{\circ} \mathrm{C}$ on $\mathrm{Cr}_{\text {eff. }}$

Fig. 3 Dependence of corrosion rate in nitric acid solutions for $30 \mathrm{~min}$ at $95^{\circ} \mathrm{C}$ on nitric acid concentration.

Values in parentheses are $\mathrm{Cr}_{\text {eff. }}$

Fig. 4 Corrosion rate suppression by addition of $\mathrm{Ru}$ and $\mathrm{V}$ to nitric acid solution.

Values in parentheses are $\mathrm{Cr}_{\text {eff. }}$.

Fig. 5 Surface optical macro image of 15P and 20P, and SEM micro image of 20P after 30-min immersion tests in $3.5 \mathrm{M}$ and $8 \mathrm{M}$ at $95^{\circ} \mathrm{C}$.

Spot No.5 of EDS analysis is matrix, and the others are particles observed as random shaped bright feature.

Fig. 6 Cathodic and anodic polarization curves of MP23 in nitric acid solutions at $95^{\circ} \mathrm{C}$.

Fig. 7 Cathodic and anodic polarization curves of steels with different $\mathrm{Cr}_{\text {eff }}$ in $3.5 \mathrm{M}$ at $95^{\circ} \mathrm{C}$.

Value in parentheses is $\mathrm{Cr}_{\text {eff }}$

Fig. 8 Schematic of the effect of $\mathrm{Cr}_{\text {eff }}$ increase, nitric acid concentration increase and addition of $\mathrm{Ru}$ and $\mathrm{V}$ on the corrosion mechanism. 


\section{Tables}

\section{Double column}

Table 1 Chemical compositions of martensitic ODS steels and a ferritic ODS steel (F14).

\begin{tabular}{|c|c|c|c|c|c|c|c|c|c|c|c|c|c|c|c|c|}
\hline \multirow{2}{*}{ Lot } & \multicolumn{16}{|c|}{ Chemical composition (wt\%) } \\
\hline & $\mathrm{C}$ & $\mathrm{Si}$ & $\mathrm{Mn}$ & $\mathrm{P}$ & $\mathrm{S}$ & $\mathrm{Ni}$ & $\mathrm{Cr}$ & $\mathrm{W}$ & $\mathrm{Ti}$ & $\mathrm{Y}$ & $\mathrm{O}$ & $\mathrm{N}$ & $\mathrm{Ar}$ & $\mathrm{Y}_{2} \mathrm{O}_{3}{ }^{1)}$ & Ex. $\mathrm{O}^{2)}$ & $\mathrm{Cr}_{\mathrm{eff}}{ }^{3)}$ \\
\hline Mm23 & 0.13 & $<0.01$ & $<0.01$ & $<0.005$ & 0.002 & $<0.01$ & 8.57 & 1.99 & 0.19 & 0.28 & 0.167 & 0.008 & 0.005 & 0.36 & 0.09 & 7.47 \\
\hline Mm19L & 0.14 & 0.05 & 0.05 & $<0.005$ & 0.001 & $<0.01$ & 8.89 & 2.02 & 0.20 & 0.27 & 0.170 & 0.010 & 0.005 & 0.34 & 0.10 & 7.69 \\
\hline MP23 & 0.13 & 0.06 & 0.05 & $<0.005$ & 0.001 & $<0.01$ & 9.08 & 1.91 & 0.22 & 0.28 & 0.140 & 0.006 & 0.005 & 0.36 & 0.06 & 8.10 \\
\hline Mod-3 & 0.14 & $<0.01$ & $<0.01$ & $<0.005$ & 0.002 & 0.33 & 10.03 & 1.44 & 0.21 & 0.27 & 0.162 & 0.003 & 0.005 & 0.34 & 0.09 & 8.83 \\
\hline $19 \mathrm{P}$ & 0.12 & 0.07 & 0.07 & 0.007 & 0.004 & 0.40 & 10.42 & 1.37 & 0.24 & 0.27 & 0.130 & 0.011 & 0.005 & 0.34 & 0.06 & 9.54 \\
\hline $15 \mathrm{P}$ & 0.14 & 0.04 & 0.05 & $<0.005$ & 0.003 & 0.40 & 10.82 & 1.28 & 0.22 & 0.27 & 0.133 & 0.006 & 0.004 & 0.34 & 0.06 & 9.72 \\
\hline $17 \mathrm{P}$ & 0.13 & 0.04 & 0.04 & 0.005 & 0.002 & 0.40 & 10.90 & 1.30 & 0.28 & 0.27 & 0.138 & 0.004 & 0.005 & 0.34 & 0.07 & 10.03 \\
\hline $20 \mathrm{P}$ & 0.13 & 0.07 & 0.07 & 0.006 & 0.003 & 0.40 & 11.21 & 1.21 & 0.23 & 0.27 & 0.130 & 0.008 & 0.005 & 0.34 & 0.06 & 10.22 \\
\hline $21 \mathrm{P}$ & 0.13 & 0.07 & 0.07 & 0.007 & 0.003 & 0.39 & 11.79 & 1.10 & 0.24 & 0.27 & 0.130 & 0.007 & 0.005 & 0.34 & 0.06 & 10.82 \\
\hline F14 & 0.04 & 0.05 & 0.09 & 0.005 & 0.004 & 0.08 & 11.37 & 1.88 & 0.26 & 0.18 & 0.110 & 0.011 & 0.005 & 0.23 & 0.06 & 11.28 \\
\hline
\end{tabular}

1) Calculated from $Y$ content with the assumption that $Y$ is present as $\mathrm{Y}_{2} \mathrm{O}_{3}$.

2) Defined as the value obtained by subtracting oxygen content as $\mathrm{Y}_{2} \mathrm{O}_{3}$ from the total $\mathrm{O}$ content in the steel.

3) Defined as the effective solute Cr concentration obtained by thermodynamic calculation. 


\section{Double column}

Table 2 Chemical compositions of conventional martensitic steel (PNC-FMS) and modified 316 steel (PNC316) used as reference materials.

\begin{tabular}{|c|c|c|c|c|c|c|c|c|c|c|c|}
\hline \multirow{2}{*}{ Lot } & \multicolumn{11}{|c|}{ Chemical composition (wt\%) } \\
\hline & $\mathrm{C}$ & $\mathrm{Si}$ & $\mathrm{Mn}$ & $\mathrm{P}$ & $\mathrm{S}$ & $\mathrm{Ni}$ & $\mathrm{Cr}$ & Mo & W & Co & B \\
\hline PNC-FMS & 0.10 & 0.07 & 0.54 & 0.002 & 0.002 & 0.32 & 11.05 & 0.45 & 1.89 & - & - \\
\hline PNC316 & 0.06 & 0.79 & 1.66 & 0.030 & 0.005 & 13.88 & 16.36 & 2.49 & - & 0.010 & 0.0043 \\
\hline & $\mathrm{N}$ & $\mathrm{Cu}$ & $\mathrm{Ti}$ & $\mathrm{V}$ & $\mathrm{Nb}$ & Ta & As & $\mathrm{Al}$ & $\mathrm{Zr}$ & $\mathrm{O}$ & $\mathrm{Cr}_{\mathrm{eff}}{ }^{1)}$ \\
\hline & 0.044 & - & - & 0.21 & 0.055 & - & - & - & - & - & 10.24 \\
\hline & 0.005 & 0.02 & 0.09 & 0.02 & 0.070 & $<0.002$ & 0.001 & 0.015 & $<0.01$ & 0.001 & 16.31 \\
\hline
\end{tabular}

1) Defined as the effective solute $\mathrm{Cr}$ concentration obtained by thermodynamic calculation. 


\section{Single column}

Table 3 Nitric acid solutions for immersion and electrochemical tests.

\begin{tabular}{ccccccccc} 
Solution & $3.5 \mathrm{M}$ & $5 \mathrm{M}$ & $8 \mathrm{M}$ & $10 \mathrm{M}$ & $12 \mathrm{M}$ & $\mathrm{S} 1$ & $\mathrm{~S} 2$ & $\mathrm{~S} 3$ \\
\hline $\mathrm{HNO}_{3}(\mathrm{~mol} / \mathrm{L})$ & 3.5 & 5 & 8 & 10 & 12 & 3.5 & 8 & 10 \\
\hline $\mathrm{V}(\mathrm{g} / \mathrm{L})$ & - & - & - & - & - & 4.4 & 1.76 & 0.88 \\
$\mathrm{Ru}(\mathrm{g} / \mathrm{L})$ & - & - & - & - & - & 2.54 & 1.02 & 0.51 \\
\hline
\end{tabular}




\section{Single column}

Table 4 Summary of surface color after 30 min immersion tests at $95^{\circ} \mathrm{C}$.

\begin{tabular}{ccccccccccc} 
& $\mathrm{Cr}_{\text {eff }}$ & \multicolumn{4}{c}{$\mathrm{HNO}_{3}$} & \multicolumn{4}{c}{ with Ru and V } \\
\cline { 3 - 10 } & (wt\%) & 3.5M & 5M & $8 \mathrm{M}$ & 10M & 12M & S1 & S2 & S3 \\
\hline \hline Mm23 & 7.47 & B & B & B & B & B & B & B & B \\
MP23 & 8.10 & B & B & B & B & B & B & S & S \\
19P & 9.54 & B & B & B & S & S & S & S & S \\
15P & 9.72 & B & B & B & B & S & S & S & S \\
17P & 10.03 & B & B & B & B & S & S & S & S \\
20P & 10.22 & B & B & S & S & S & S & S & S \\
PNC-FMS & 10.24 & S & S & S & S & S & S & S & S \\
21P & 10.82 & B & S & S & S & S & S & S & S \\
F14 & 11.28 & S & S & S & S & S & S & S & S \\
PNC316 & 16.31 & S & S & S & S & S & S & S & S \\
\hline
\end{tabular}

B: Black or Brown S: Silver 


\section{Figures}

Single column

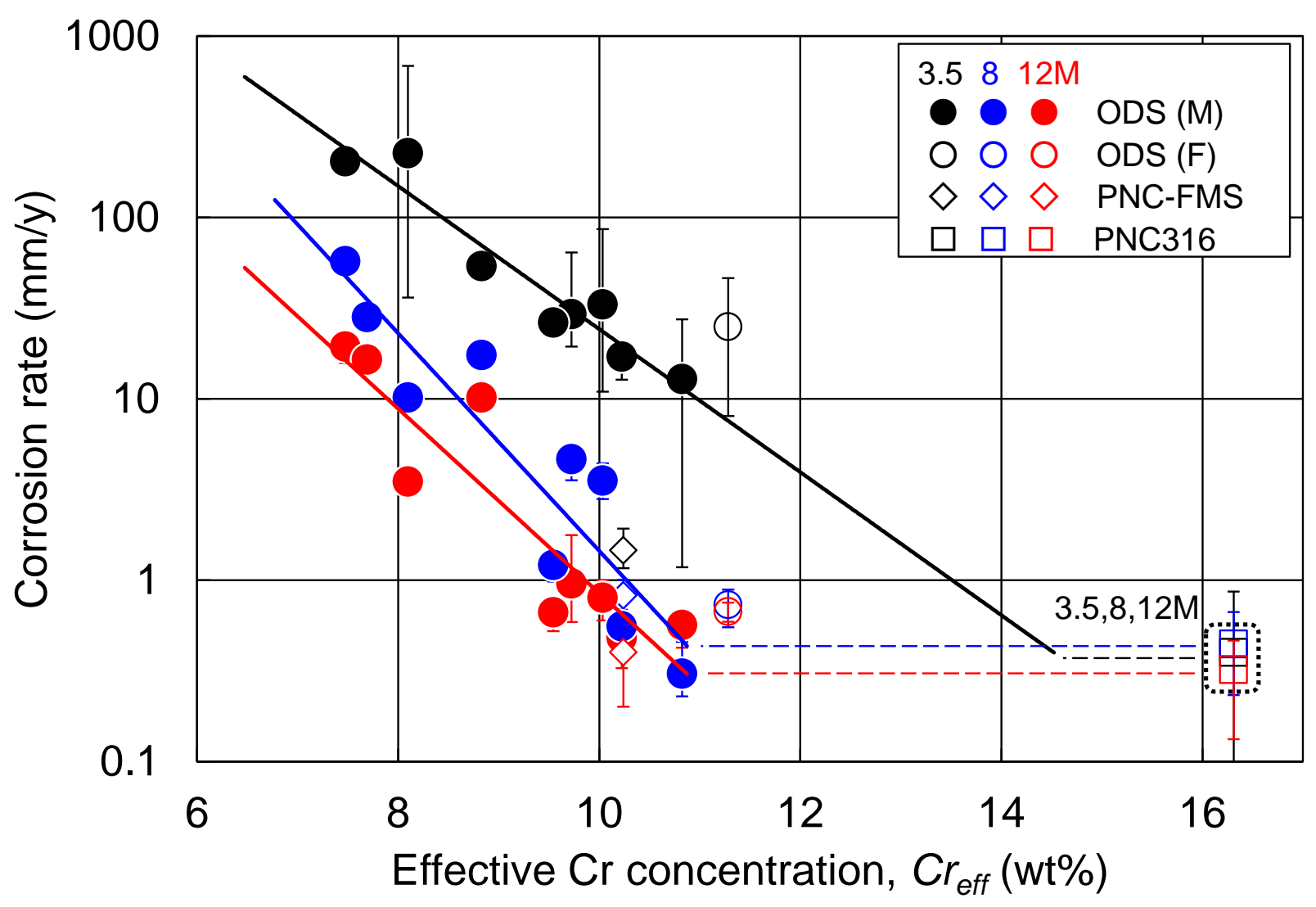

Fig. 1 Dependence of corrosion rate in nitric acid solutions for $30 \mathrm{~min}$ at $95^{\circ} \mathrm{C}$ on $\mathrm{Cr}_{\text {eff. }}$. 
Single column

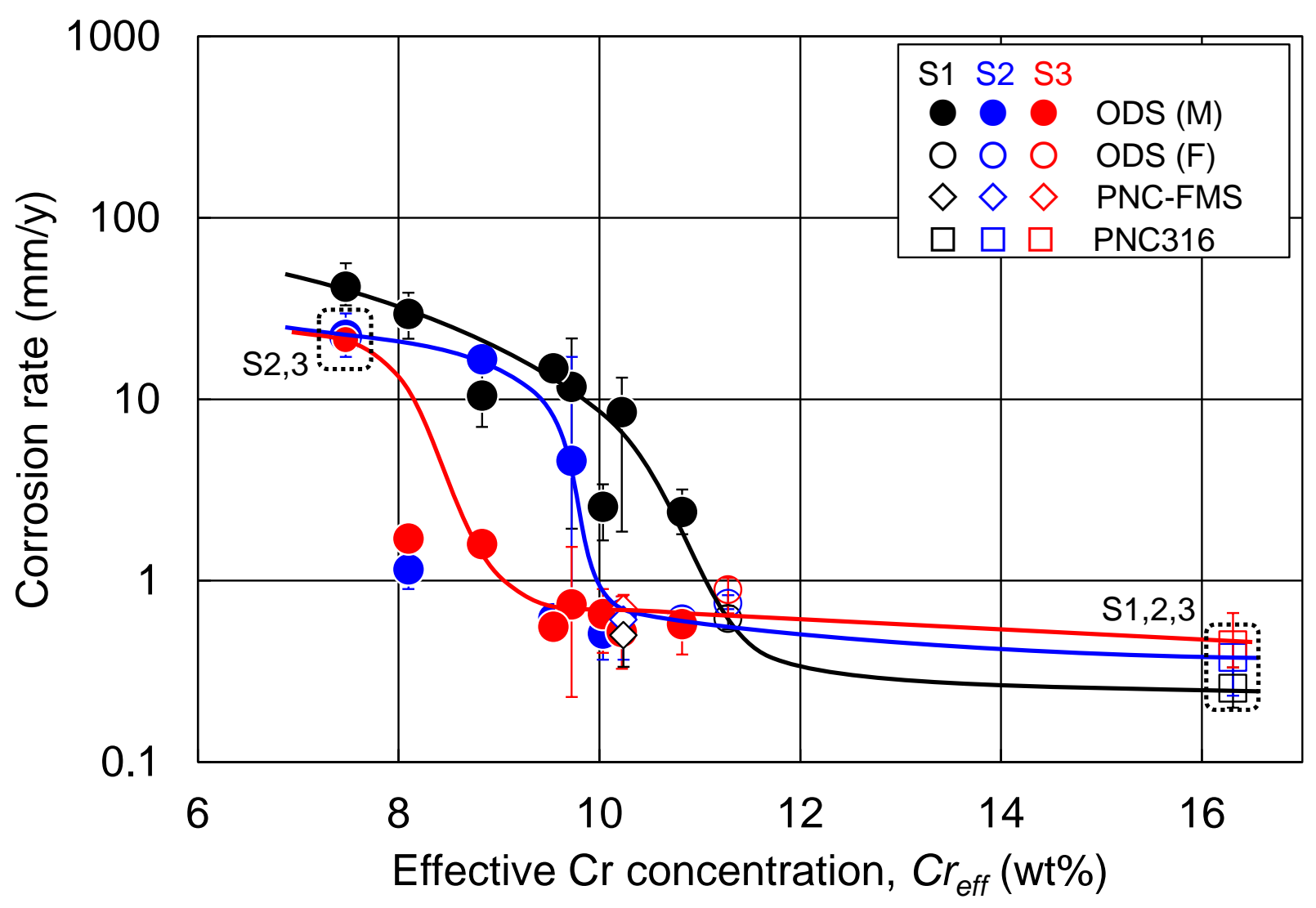

Fig. 2 Dependence of corrosion rate in nitric acid solutions with $\mathrm{Ru}$ and $\mathrm{V}$ for $30 \mathrm{~min}$ at $95^{\circ} \mathrm{C}$ on $\mathrm{Cr}_{\text {eff. }}$. 


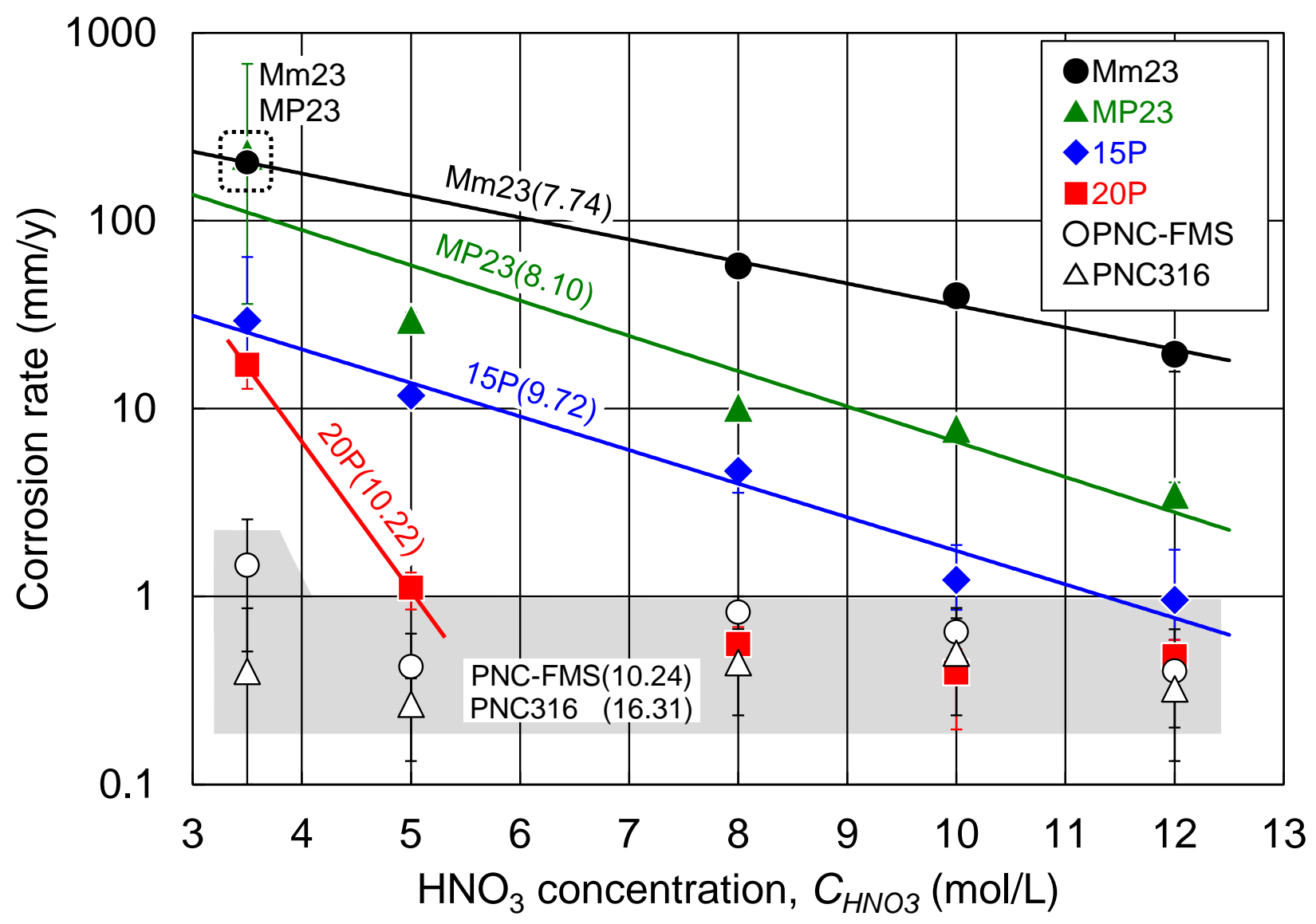

Fig. 3 Dependence of corrosion rate in nitric acid solutions for $30 \mathrm{~min}$ at $95^{\circ} \mathrm{C}$ on nitric acid concentration. Values in parentheses are $\mathrm{Cr}_{\text {eff. }}$ 
Single column

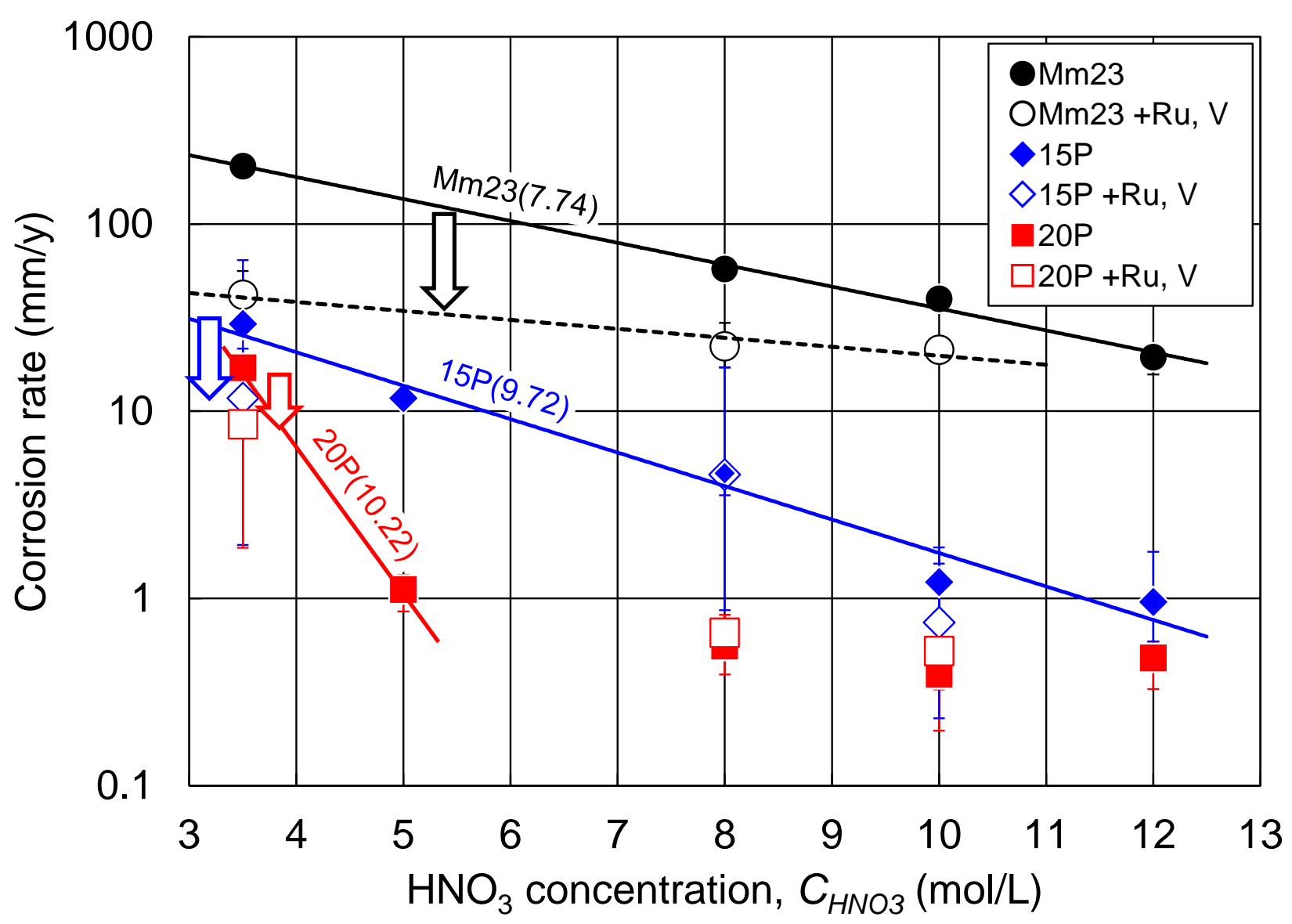

Fig. 4 Corrosion rate suppression by addition of $\mathrm{Ru}$ and $\mathrm{V}$ to nitric acid solution. Values in parentheses are $\mathrm{Cr}_{\text {eff. }}$ 


\section{Double column}

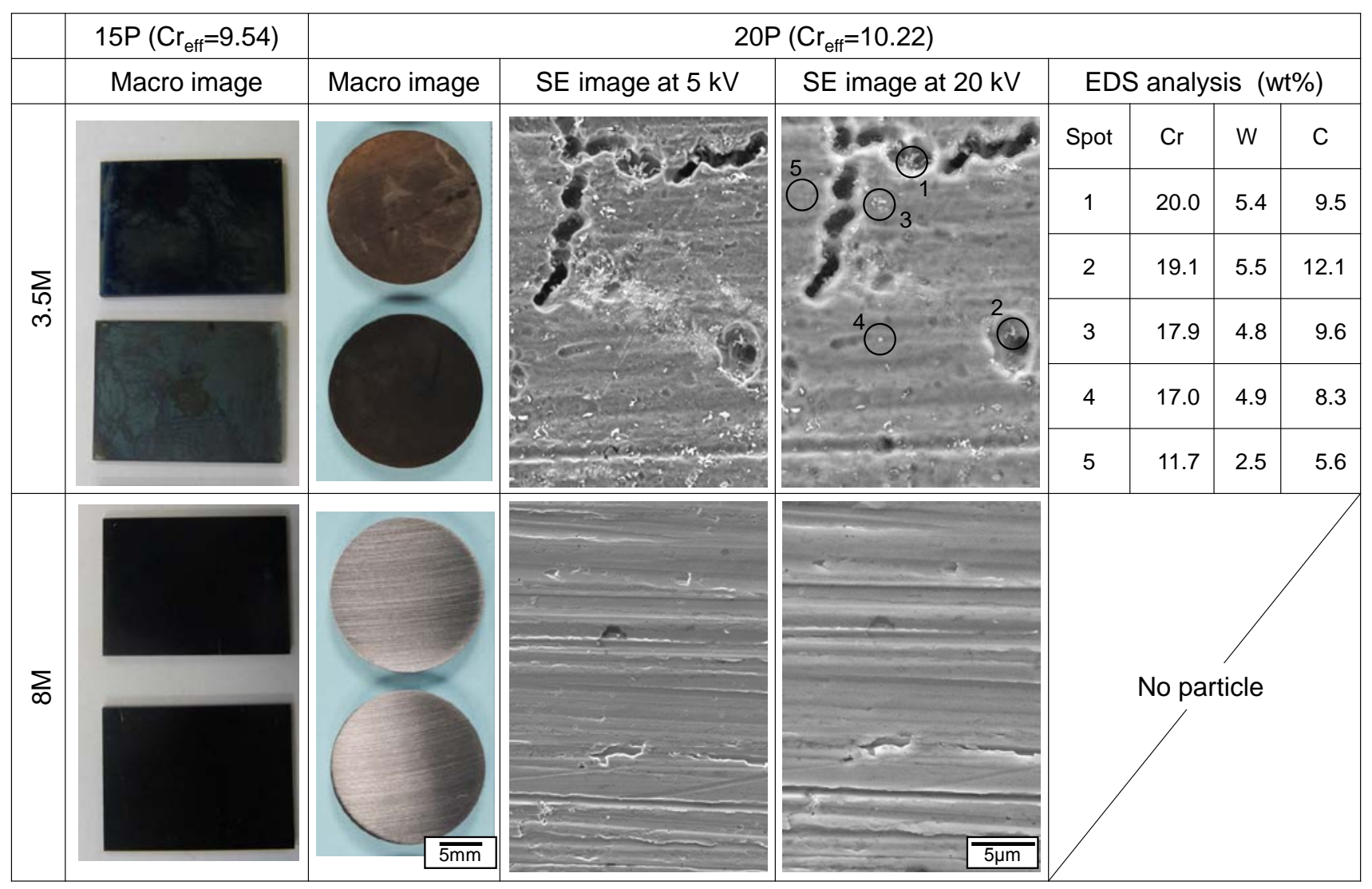

Fig. 5 Surface optical macro image of 15P and 20P, and SEM micro image of 20P after 30-min immersion tests in $3.5 \mathrm{M}$ and $8 \mathrm{M}$ at $95^{\circ} \mathrm{C}$.

Spot No.5 of EDS analysis is matrix, and the others are particles observed as random shaped bright feature. 
Single column

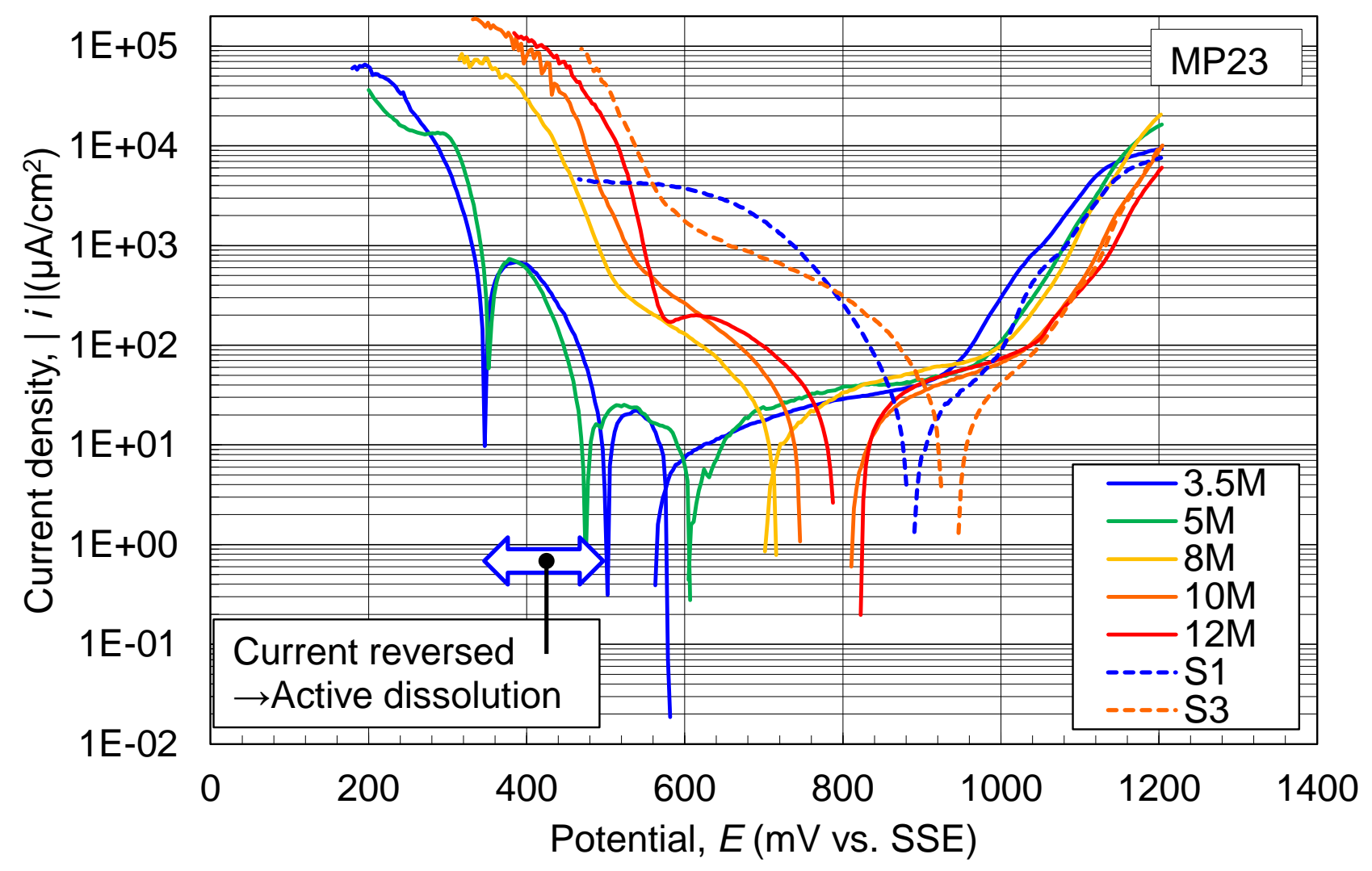

Fig. 6 Cathodic and anodic polarization curves of MP23 in nitric acid solutions at $95^{\circ} \mathrm{C}$. 
Single column

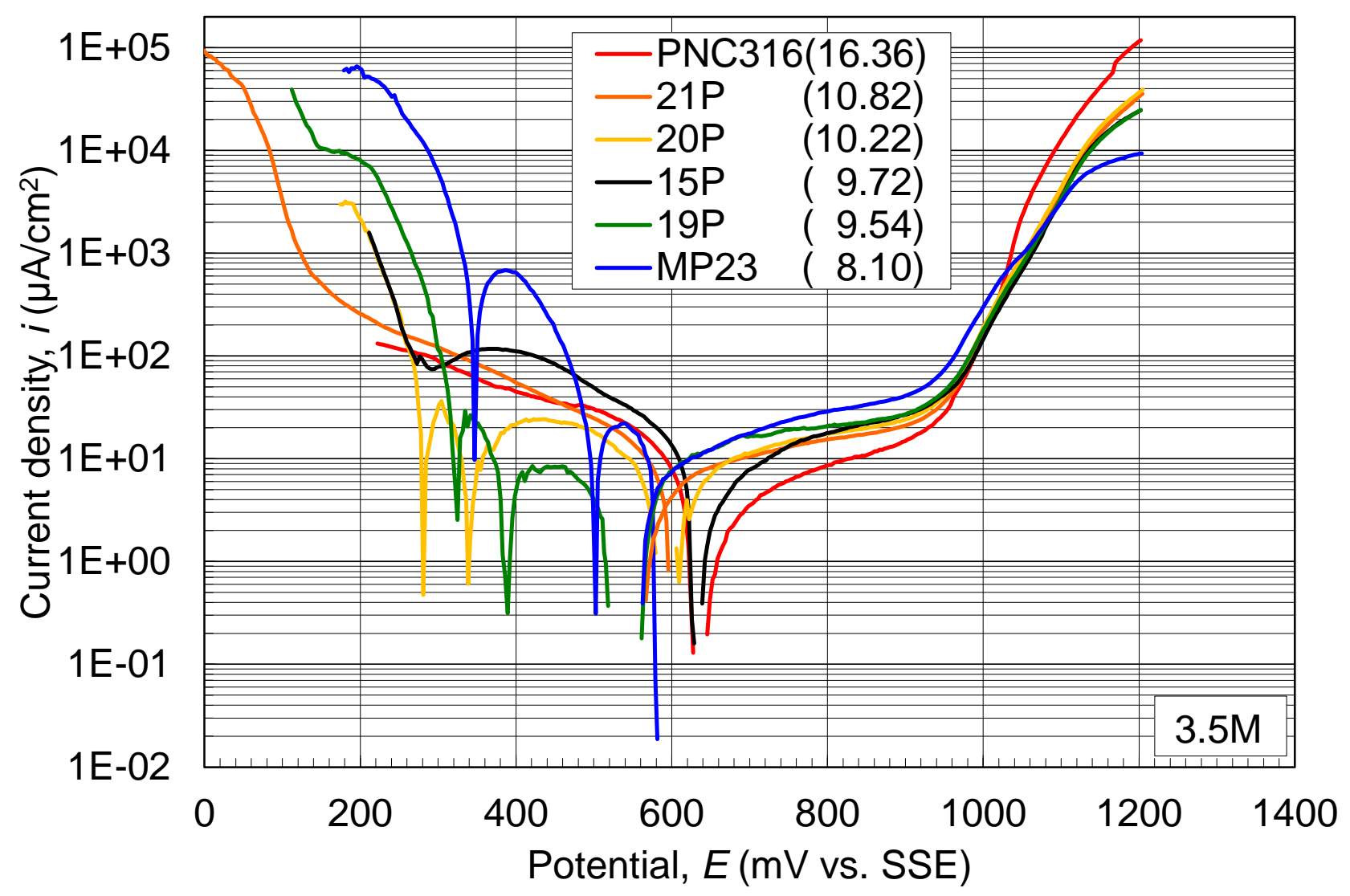

Fig. 7 Cathodic and anodic polarization curves of steels with different $\mathrm{Cr}_{\text {eff }}$ in $3.5 \mathrm{M}$ at $95^{\circ} \mathrm{C}$.

Values in parentheses are $\mathrm{Cr}_{\text {eff. }}$. 
Single column

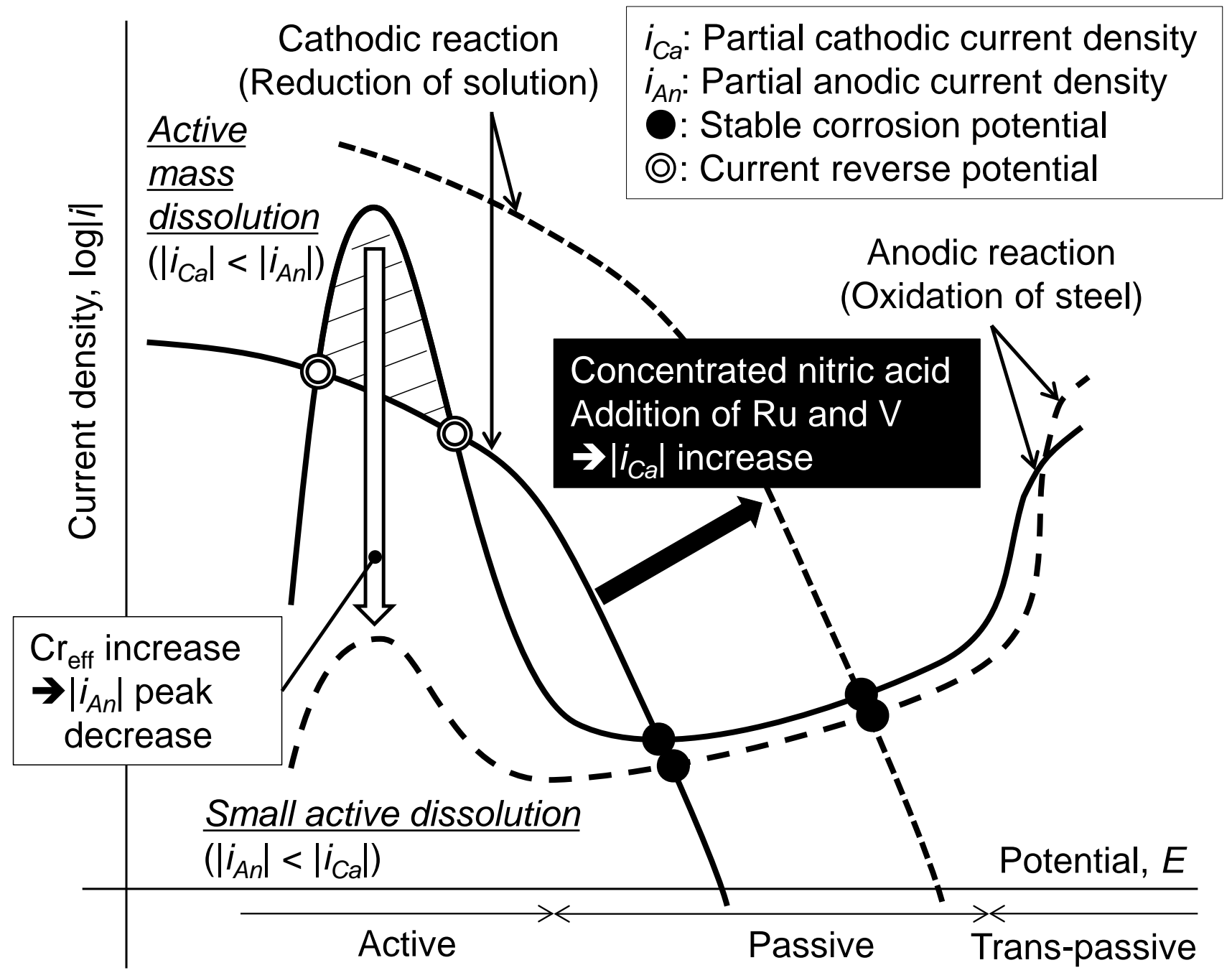

Fig. 8 Schematic of the effect of $\mathrm{Cr}_{\text {eff }}$ increase, nitric acid concentration increase and addition of $\mathrm{Ru}$ and $\mathrm{V}$ on the corrosion mechanism. 